\title{
KONFLIK ASET DAERAH ANTARPEMERINTAH DAERAH PASCA-PEMEKARAN: STUDI KASUS KONFLIK KEPEMILIKAN BANGUNAN ANTARA PEMERINTAH KABUPATEN KERINCI DENGAN KOTA SUNGAIPENUH PROVINSI JAMBI
}

\author{
Oleh \\ Indra Hermawan ${ }^{1}$, \\ Tjahya Supriatna ${ }^{2}$, Ali Hanafiah Muhi $^{3}$ \\ 1) Pemerintah Kabupaten Kerinci, Kantor Kelurahan Lempur Tengah \\ Program Magister Terapan Studi Pemerintahan Daerah Institut Pemerintahan Dalam Negeri \\ indra.jegerr@gmail.com \\ 2,3) Institut Pemerintahan Dalam Negeri
}

\begin{abstract}
$T$ The focus of this research was to settlement of regional asset conflicts (building assets) between the Kerinci district government and the Sungaipenuh City, the factors cause of conflict and determine the strategies used to provide solutions for resolving regional asset conflicts (building assets) between the Kerinci district government and the Sungaipenuh City.

The research uses theory by Winardi related to solving conflict in an integrative problem solving and uses Boedi Wijarjo theory to see the factors that cause conflict and conduct a SWOT analysis and Litmus test to determine strategies.

This research uses a qualitative method with a descriptive approach. In collecting data, researchers conducted observations, interviews and collected documents on the regional asset conflicts (building assets) between the Kerinci district government and the Sungaipenuh City.

The results showed that settlement of regional asset conflicts (building assets) between the Kerinci district government and the Sungaipenuh City by using consensus and confrontation has not run optimally and the use of superordinate goals has never been implemented. The factors that cause conflict that affect consist of structural factors, interest factors, value factors, human relations factors, and data conflicts then determine the strategies used to provide solutions for resolving regional asset conflicts (building assets) between the Kerinci district government and the Sungaipenuh City based on the SWOT analysis and Litmus test, the most strategic issues were: carry out further mediation on resolving regional asset conflicts (building assets) between the two regional governments, provide solutions for compensation for building assets to the district government of Kerinci, giving consideration to resolving regional asset conflicts (building assets) between the two regional governments must be complete and not take sides with one of the regional governments, provide solutions for cooperation with productive regional assets to both local governments.
\end{abstract}

Keywords: regional conflict asset, local government, building ownership 


\section{Abstrak}

$\mathrm{P}$ enelitian ini difokuskan pada penyelesaian konflik aset daerah (aset bangunan) antara Pemerintah Kabupaten Kerinci dengan Kota Sungaipenuh, faktor-faktor penyebab konflik serta menentukan strategi yang sebaiknya dilakukan untuk memberikan solusi penyelesaian konflik aset daerah (aset bangunan) antara Pemerintah Kabupaten Kerinci dengan Kota Sungaipenuh.

Penelitian menggunakan teori oleh Winardi terkait pemecahan konflik secara pemecahan problem integratif dan menggunakan teori menurut Boedi Wijarjo dan untuk melihat faktorfaktor penyebab konflik serta melakukan analisis SWOT dan Litmus test untuk menentukan strategi.

Penelitian ini menggunakan metode kualitatif dengan pendekatan deskriptif. Dalam mengumpulkan data, peneliti melakukan observasi, wawancara dan mengumpulkan dokumen tentang konflik aset daerah (aset bangunan) antara Pemerintah Kabupaten Kerinci dengan Kota Sungaipenuh.

Hasil penelitian menunjukkan bahwa penyelesaian konflik aset daerah (aset bangunan) antara Pemerintah Kabupaten Kerinci dengan Kota Sungaipenuh dengan menggunakan konsensus dan konfrontasi belum berjalan secara optimal serta penggunaan tujuan-tujuan superordinat belum pernah dilaksanakan. Faktor-faktor penyebab konflik yang memengaruhi terdiri dari faktor struktural, faktor kepentingan, faktor nilai, faktor hubungan antarmanusia, dan konflik data yang kemudian ditentukan strategi yang sebaiknya dilakukan untuk memberikan solusi penyelesaian konflik aset daerah (aset bangunan) antara Pemerintah Kabupaten Kerinci dengan Kota Sungaipenuh berdasarkan analisis SWOT dan Litmus test didapatkan isu sangat strategis antara lain: melaksanakan mediasi lanjutan penyelesaian konflik aset daerah (aset bangunan) antarkedua pemerintah daerah; memberikan solusi ganti rugi aset bangunan kepada pemerintah kabupaten Kerinci; pemberian pertimbangan penyelesaian konflik aset daerah (aset bangunan) antarkedua pemerintah daerah harus tuntas dan tidak memihak salah satu pemerintah daerah; memberikan solusi kerja sama terhadap aset daerah yang produktif kepada kedua pemerintah daerah.

Kata kunci: konflik aset daerah, pemerintah daerah, kepemilikan bangunan

\section{PENDAHULUAN}

$\mathrm{K}_{\mathrm{p}}^{\mathrm{e}}$ ebijakan otonomi daerah membuka peluang bagi Pemerintah Provinsi dan Pemerintah Kabupaten/Kota untuk membangun dan mengembangkan daerahnya sendiri. Perubahan penyelenggaraan pemerintahan daerah pada era reformasi dari sentralisasi ke arah desentralisasi menuntut masyarakat untuk lebih aktif lagi dalam menyampaikan aspirasinya, sebagaimana yang diatur dalam UndangUndang No. 23 Tahun 2014 tentang Pemerintahan Daerah.

Dalam pelaksanaan otonomi daerah tentunya tidak sama antara setiap daerah dengan daerah lainnya, sehingga sering terjadi konflik antardaerah yang harus diselesaikan dengan segera oleh pemerintah pusat baik itu masalah batas wilayah, aset daerah, pendapatan asli daerah, dan lain-lain. Contoh dari konflik daerah yang masih berlanjut hingga sekarang adalah permasalahan aset daerah antara pemerintah Kabupaten Kerinci dan Kota Sungaipenuh.

\section{Selama Pasca-Pemekaran Daerah} ini, Kota Sungaipenuh terkesan hanya menggantungkan pada Dana Perimbangan yaitu Dana Alokasi Umum (DAU) dan Dana Alokasi Khusus (DAK) dari Pemerintah Pusat. Sudah seharusnya sekarang Kota Sungaipenuh mengubah mindset dengan tidak menggantungkan sumber dana pembangunan daerah dari pusat 
melalui Dana Alokasi Umum dan Dana Alokasi Khusus, tetapi Kota Sungaipenuh dituntut untuk lebih mengoptimalkan dan memaksimalkan sumber daya yang ada di daerahnya serta menciptakan sumbersumber Pendapatan Asli Daerah yang baru.

Permasalahan lain yang ditimbulkan dari Pemekaran daerah antara Kabupaten Kerinci dan Kota Sungaipenuh adalah Kabupaten Kerinci sebagai Kabupaten induk yang harus memindahkan ibu kota kabupaten ke luar dari Kota Sungaipenuh (Kecamatan Siulak di Bukittengah). Sehingga aset daerah yang ada di Kota Sungaipenuh sebagian besar masih digunakan oleh Pemerintah Kabupaten Kerinci sebagai kabupaten induk.

Keinginan Pemerintah Kota Sungaipenuh untuk menguasai aset secara penuh adalah hal yang wajar sebagai konsekuensi yuridis berlakunya Undang-Undang No. 25 Tahun 2008 tentang Pembentukan Kota Sungaipenuh. Begitu juga sebaliknya adalah hal yang wajar ketika Pemerintah Kabupaten Kerinci merasa keberatan dan mempersoalkan beberapa pasal dalam undang-undang tersebut, khususnya yang berkaitan dengan aset. Tidak dapat dipungkiri sengketa aset ini muncul setelah dimekarkannya Kabupaten Kerinci menjadi dua wilayah yakni Kabupaten Kerinci dan Kota Sungaipenuh. Sebagian pihak menganggap pemekaran Kabupaten Kerinci masih menyisakan polemik terutama masalah aset yang berimbas memburuknya hubungan antara Penjabat Kota Sungaipenuh dengan Penjabat Kabupaten Kerinci yang juga tentunya akan berpengaruh buruk terhadap percepatan pembangunan di kedua wilayah.

Dengan pemekaran wilayah diharapkan dapat memunculkan pusat-pusat pertumbuhan ekonomi baru, mampu meningkatkan berbagai potensi yang selama ini belum tergarap secara optimal, baik potensi sumber daya alam maupun sumber daya manusia, membuka keterkungkungan masyarakat terhadap pembangunan dan dapat memutus mata rantai pelayanan yang sebelumnya terpusat di satu tempat atau ibu kota kabupaten atau ibu kota kecamatan, memicu motivasi masyarakat untuk ikut secara aktif dalam proses pembangunan dalam rangka meningkatkan taraf hidup masyarakat setempat. Namun apa yang terjadi sekarang, Pemekaran Kabupaten Kerinci dengan dibentuknya Kota Sungaipenuh yang awalnya diharapkan dapat menyelesaikan masalah ternyata malah sebaliknya, pemekaran terkesan telah melahirkan masalah baru. Salah satunya adalah sengketa aset, khususnya aset yang dianggap produktif. Beberapa aset yang disengketakan di antaranya adalah Perusahaan Daerah Air Minum (PDAM) Tirta Sakti, Rumah Sakit Umum, Gedung Nasional, Kantor Bupati dan Wakil Bupati Kerinci yang ada di Kota Sungaipenuh dan Kincai Plaza yang menjadi pusat perbelanjaan terbesar di wilayah Kerinci dan Sungaipenuh.

\section{KERANGKA TEORI}

\section{Aset Daerah}

Menurut Siregar (2004: 178) pengertian aset yaitu sebagai berkut.

Aset adalah barang yang dalam pengertian hukum disebut benda, yang terdiri dari benda tidak bergerak dan benda bergerak. Barang yang dimaksud meliputi barang tidak bergerak (tanah dan bangunan) dan barang bergerak baik yang berwujud maupun yang tidak berwujud, yang tercakup dalam aktiva/ kekayaan atau harta kekayaan dari suatu perusahaan, badan usaha, institusi atau individu perorangan.

Dalam Peraturan Menteri Dalam Negeri No. 19 Tahun 2016 menjelaskan Pemegang Kekuasaan Pengelolaan Barang Milik Daerah adalah Gubernur/Bupati/Wali kota yang dibantu oleh: 
a) Sekretaris Daerah (selaku Pengelola Barang);

b) Kepala Satuan Kerja Perangkat Daerah (selaku Pejabat Penatausahaan Barang);

c) Kepala Satuan Kerja Perangkat Daerah (selaku Pengguna Barang);

d) Pejabat Penatausahaan Barang dan Pengguna Barang ditetapkan dengan Keputusan Gubernur/Bupati/Wali kota

Berdasarkan Pernyataan Standar Akuntansi Pemerintahan No. 15, Gedung dan Bangunan dapat diklasifikasikan menurut jenisnya, seperti gedung perkantoran, rumah dinas, bangunan tempat ibadah, menara, monumen/bangunan bersejarah, gudang, gedung museum. Aset tetap diakui pada saat manfaat ekonomi masa depan dapat diperoleh dan nilainya dapat diukur dengan handal. Untuk dapat diakui sebagai aset tetap harus dipenuhi kriteria sebagai berikut.

a) Berwujud;

b) Mempunyai masa manfaat lebih dari dua belas bulan;

c) Biaya perolehan aset dapat diukur secara andal;

d) Tidak dimaksudkan untuk dijual dalam operasi normal entitas; dan

e) Diperoleh atau dibangun dengan maksud untuk digunakan.

Berdasarkan Pernyataan Standar Akuntansi Pemerintahan No. 7 (PSAP No. 7) yang berpedoman Pada Peraturan Pemerintah No. 24 Tahun 2005 tentang Standar Akuntansi Pemerintahan, aset tetap adalah aset berwujud yang mempunyai masa manfaat lebih dari dua belas bulan untuk digunakan dalam kegiatan pemerintah atau dimanfaatkan oleh masyarakat umum.

\section{Konflik}

Menurut Antonius (2002: 175) konflik adalah suatu tindakan salah satu pihak yang berakibat menghalangi, menghambat atau mengganggu pihak lain di mana hal ini dapat terjadi antarkelompok masyarakat ataupun hubungan antarpribadi.

Menurut Wijarjo (2001: 52) menjelaskan sumber pokok konflik atas sumber daya alam pada umumnya bersifat struktural, dengan melibatkan unsur-unsur lainnya. Sumbersumber konflik dapat dijelaskan sebagai berikut.

a. Masalah Struktural, yang dimaksud di sini adalah sebab-sebab konflik yang berkaitan dengan kekuasaan, wewenang formal, kebijakan umum (baik dalam bentuk peraturan perundang-undangan maupun kebijakan formal lainnya), dan juga persoalan geografis dan faktor sejarah.

b. Faktor kepentingan, menimbulkan konflik karena adanya persaingan kepentingan yang dirasakan atau yang secara nyata memang tidak bersesuaian. Konflik kepentingan ini terjadi ketika salah satu pihak atau lebih meyakini bahwa untuk memuaskan kebutuhan/ keinginannya, pihak lain harus berkorban.

c. Perbedaan nilai, yang dimaksud di sini adalah konflik disebabkan oleh sistem-sistem kepercayaan yang tidak bersesuaian entah itu dirasakan atau memang ada.

d. Konflik hubungan antarmanusia, konflik ini terjadi karena adanya emosi-emosi negatif yang kuat, salah persepsi, atau streotip, salah komunikasi, atau tingkah laku negatif yang berulang.

e. Konflik data, konflik ini terjadi ketika orang kekurangan informasi yang salah, tidak sepakat mengenai apa saja data yang relevan, menerjemahkan informasi dengan cara yang berbeda atau memakai tata cara pengkajian yang berbeda.

Menurut Winardi (2007: 88) pemecahan problem integratif, dengan metode ini konflik antarkelompok dialihkan menjadi sebuah situasi pemecahan masalah bersama 
yang dapat dipecahkan dengan bantuan teknik-teknik pemecahan masalah. Ada tiga bentuk tipe mode penyelesaian konflik secara integratif yaitu:

$\checkmark$ Konsensus (concencus), yang dinamakan konsensus adalah pihak-pihak yang berkonflik bertemu untuk menemukan pemecahan terbaik bagi masalah yang ada dan mereka bukan berupaya untuk kemenangan di masing-masing pihak.

$\checkmark$ Konfrontasi (confrontation), dalam hal ini pihak yang berkonflik menyatakan pandangan mereka masing-masing secara langsung kepada pihak lain. Kemudian alasan-alasan mengapa terjadinya konflik dipelajari dan metodemetode penyelesaian konflik dicarikan solusinya.

$\checkmark$ Penggunaan tujuan-tujuan superordinat (superordinate goals), ditetapkannya tujuan-tujuan superordinat juga dapat menjadi sebuah metode penyelesaian konflik andaikata tujuan tingkat lebih tinggi yang disetujui semua pihak juga mencakup tujuan-tujuan tingkat lebih rendah dari pihak-pihak yang berkonflik satu sama lain. Perlu diingat bahwa upaya untuk mengejar sebuah tujuan superordinat bukan saja menyelesaikan konflik antara pihak yang bertentangan satu sama lain, tetapi dapat juga membantu menjalin kerja sama antarkelompok.

\section{METODE PENELITIAN}

Penelitian menggunakan metode penelitian kualitatif dengan pendekatan deskriptif. Informan penelitian sebanyak 16 orang ditentukan dengan purposive sampling technique.

Pengumpulan data menggunakan observasi, wawancara, dan dokumentasi. Analisis data menggunakan data reduction, data displai, dan conclusion drawing/ verification.

\section{HASIL DAN PEMBAHASAN}

\section{Konsensus}

Menurut Winardi (2007: 88) konsensus (concencus), yang dinamakan konsensus adalah pihak-pihak yang berkonflik bertemu untuk menemukan pemecahan terbaik bagi masalah yang ada dan mereka bukan berupaya untuk kemenangan di masingmasing pihak.

Berdasarkan Surat Wali kota Sungaipenuh No.130/Kep.315/2009 tentang Penunjukan Tim Fasilitasi Percepatan Penyerahan Personel, Pendanaan, Sarana dan Prasarana dan Dokumentasi Kota Sungaipenuh. Pembentukan Tim P3D Kota Sungaipenuh ini tidak saja terdiri dari Pejabat Pemerintah Kota Sungaipenuh namun juga terdiri dari tokoh adat dan tokoh masyarakat Kota Sungaipenuh.

Berdasarkan data di atas, bahwa penyelesaian konflik aset daerah (aset bangunan) dalam bentuk Konsensus yang telah dilakukan Pemerintah Kabupaten Kerinci dan Kota Sungaipenuh tidak dapat diselesaikan antara kedua Pemerintah Daerah tersebut dikarenakan tingkatan antara kedua pemerintah daerah tersebut sama tugas dan wewenangnya dalam mengurus wilayah/daerah sehingga belum ditemukannya kesepakatan bersama antara kedua Pemerintahan Daerah Tersebut. Oleh karena itu, harus adanya campur tangan dari Pemerintah Pusat dan Pemerintah Provinsi (Kementerian Dalam Negeri dan Pemerintah Provinsi Jambi) dalam menyelesaikan sengketa aset daerah (aset bangunan) tersebut antara Pemerintah Kabupaten Kerinci dan Pemerintah Kota Sungaipenuh.

\section{Konfrontasi}

Menurut Winardi (2007: 88) konfrontasi (confrontation) sebagai bentuk cara penyelesaian konflik, dalam hal ini pihak yang berkonflik menyatakan pandangan mereka masing-masing secara langsung 
kepada pihak lain. Kemudian alasan-alasan mengapa terjadinya konflik dipelajari dan metode-metode penyelesaian konflik dicarikan solusinya.

Berdasarkan Undang-Undang No. 25 Tahun 2008 tentang Pembentukan Kota Sungaipenuh Pasal 13 ayat (8) menjelaskan apabila penyerahan dan pemindahan aset serta dokumen sebagaimana dimaksud pada ayat (7) tidak dilaksanakan oleh Bupati Kerinci, Gubernur Jambi selaku wakil Pemerintah wajib menyelesaikannya. Kemudian Pasal 13 ayat (9) menjelaskan pelaksanaan pemindahan personel serta penyerahan aset dan dokumen sebagaimana dimaksud pada ayat (1) dilaporkan oleh Gubernur Jambi kepada Menteri Dalam Negeri.

Berdasarkan Surat Menteri Dalam Negeri atas nama Direktur Jenderal Bina Keuangan Daerah No. T.005/35.86/ Keuda pada 30 September 2016 tentang Penyelesaian Permasalahan Terkait Hibah Bantuan Keuangan Antara Provinsi dan Kabupaten Induk terhadap Daerah Otonomi Baru Sebagaimana Diamanatkan dalam Undang-Undang Pembentukan Daerah Otonomi Baru. Surat Keputusan Menteri Dalam Negeri atas nama Direktur Jenderal Bina Keuangan Daerah Menindaklanjuti Hasil Rapat Koordinasi antara Direktorat Jenderal Bina Keuangan Daerah Kementerian Dalam Negeri dengan Direktorat Jenderal Perimbangan Keuangan Kementerian Keuangan pada 9 Agustus 2016 Terkait Penyelesaian Permasalahan Bantuan Keuangan/Hibah Bagi Daerah Otonomi Baru (DOB).

Berdasarkan Peraturan Presiden No. 91 Tahun 2015 tentang Dewan Pertimbangan Otonomi Daerah Pasal 3 berbunyi:

"Dewan Pertimbangan Otonomi Daerah mempunyai tugas memberikan pertimbangan kepada Presiden mengenai rancangan kebijakan yang meliputi: a. Penataan daerah;

b. Dana dalam rangka penyelenggaraan otonomi khusus;

c. Dana perimbangan keuangan antara Pemerintah Pusat dan Daerah;

d. Penyelesaian permasalahan dalam penyelenggaraan pemerintahan daerah dan/atau perselisihan antara daerah dengan kementerian/lembaga pemerintah non-kementerian."

Selanjutnya, Pasal 4 ayat (1) berbunyi:

Untuk melaksanakan tugas sebagaimana dimaksud dalam Pasal 3, DPOD menyelenggarakan fungsi:

a. pemberian pertimbangan terhadap hasil penilaian dan kajian atas usulan pembentukan daerah;

b. pemberian pertimbangan atas rancangan kebijakan penyelesaian permasalahan yang diakibatkan oleh adanya pembentukan daerah dan penyesuaian daerah;

c. pemberian pertimbangan atas rancangan kebijakan dana dalam rangka penyelenggaraan otonomi khusus yang terdiri dari dana otonomi khusus dan dana tambahan infrastruktur serta dana keistimewaan;

d. pemberian pertimbangan atas rancangan kebijakan dana bagi hasil, dana alokasi umum, dan dana alokasi khusus untuk setiap tahun anggaran sesuai dengan ketentuan peraturan perundang-undangan; dan

e. pemberian pertimbangan atas kebijakan penyelesaian permasalahan dalam penyelenggaraan urusan Pemerintahan Daerah dan/ atau perselisihan antara daerah provinsi/kabupaten/kota dengan kementerian/lembaga pemerintah non-kementerian. 
Pasal 6 ayat (1) berbunyi:

Susunan keanggotaan DPOD terdiri atas:

a. Wakil Presiden selaku ketua merangkap anggota;

b. Menteri Dalam Negeri selaku sekretaris merangkap anggota;

c. Menteri Keuangan selaku wakil sekretaris merangkap anggota;

d. Para Menteri terkait sebagai anggota; dan

e. Perwakilan kepala daerah sebagai anggota.

Berdasarkan data di atas, bahwa penyelesaian konflik aset daerah (aset bangunan) dalam bentuk Konfrontasi yang telah dilakukan Kementerian Dalam Negeri dan Pemerintah Provinsi Jambi kepada Pemerintah Kabupaten Kerinci dan Kota Sungaipenuh, untuk penyelesaian bantuan hibah keuangan bagi Daerah Otonomi Baru (DOB) telah diselesaikan dengan baik permasalahannya. Akan tetapi permasalahan aset daerah (aset bangunan) antara kedua pemerintah daerah tersebut belum menemukan kesepakatan bersama dan masih akan dipelajari lebih lanjut, bagaimana solusi penyelesaian konflik aset daerah (aset bangunan) tersebut dapat terselesaikan secara efektif, efisien, tuntas dan tanpa merugikan salah satu pemerintah daerah yang sedang berkonflik. Jika, Pemerintah Provinsi Jambi tidak dapat menyelesaikan perkara aset daerah (aset bangunan) tersebut, maka Pemerintah Provinsi Jambi menaikkan surat permohonan bantuan penyelesaian konflik aset daerah (aset bangunan) antara Pemerintah Kabupaten Kerinci dan Pemerintah Kota Sungaipenuh kepada Kementerian Dalam Negeri. Maka, Kementerian Dalam Negeri akan membentuk Dewan Pertimbangan Otonomi Daerah untuk ikut andil dalam penyelesaian konflik aset daerah (aset bangunan) antara Pemerintah Kabupaten Kerinci dan Pemerintah Kota Sungaipenuh sesuai dengan amanat
Peraturan Presiden No. 91 Tahun 2015 tentang Dewan Pertimbangan Otonomi Daerah (DPOD).

\section{Penggunaan Tujuan-Tujuan Super- ordinat}

MenurutWinardi(2007:88)menjelaskan Penggunaan tujuan-tujuan superordinat (superordinate goals) sebagai bentuk cara penyelesaian konflik, ditetapkannya tujuantujuan superordinat juga dapat menjadi sebuah metode penyelesaian konflik andaikata tujuan tingkat lebih tinggi yang disetujui semua pihak juga mencakup tujuantujuan tingkat lebih rendah dari pihak-pihak yang berkonflik satu sama lain. Perlu diingat bahwa upaya untuk mengejar sebuah tujuan superordinat bukan saja menyelesaikan konflik antara pihak yang bertentangan satu sama lain, tetapi dapat juga membantu menjalin kerja sama antarkelompok.

Berdasarkan teori penyelesaian konflik aset daerah (aset bangunan) dalam bentuk Penggunaan Tujuan-Tujuan Superordinat yang dilakukan Kementerian Dalam Negeri dan Pemerintah Provinsi Jambi kepada Pemerintah Kabupaten Kerinci dan Kota Sungaipenuh belum pernah dilaksanakan. Dikarenakan Kementerian Dalam Negeri memberikan wewenang penyelesaian permasalahan konflik kepada Pemerintah Provinsi Jambi untuk menyelesaikan permasalahan aset daerah (aset bangunan antara Pemerintah Kabupaten Kerinci dan Pemerintah Kota Sungaipenuh. Sedangkan Pemerintah Provinsi Jambi masih mempelajari terlebih dahulu bagaimana penyelesaian konflik aset daerah antara kedua pemerintah daerah tersebut dapat diselesaikan secara efektif, efisien, tuntas dan kebijakan yang akan diambil dalam penyelesaian konflik tidak merugikan antara kedua Pemerintah Daerah tersebut. 


\section{SIMPULAN}

a. Konsensus yang telah dilaksanakan dalam penyelesaian konflik aset daerah (aset bangunan) antara Pemerintah Kabupaten Kerinci dan Pemerintah Kota Sungaipenuh, tidak dapat diselesaikan antara kedua Pemerintah Daerah tersebut dikarenakan tingkatan antara kedua pemerintah daerah tersebut sama tugas dan wewenangnya dalam mengurus wilayah/daerah sehingga belum ditemukannya kesepakatan bersama antara kedua Pemerintahan Daerah Tersebut.

b. Konfrontasi yang merupakan alternatif kedua dari pemecahan problem integratif yang telah dilaksanakan Pemerintah Provinsi Jambi dalam penyelesaian konflik aset daerah (aset bangunan) antara Pemerintah Kabupaten Kerinci dan Pemerintah Kota Sungaipenuh, belum menemukan kesepakatan bersama dan masih akan dipelajari lebih lanjut, bagaimana solusi penyelesaian konflik aset daerah (aset bangunan) tersebut dapat terselesaikan secara efektif, efisien, tuntas dan tanpa merugikan salah satu pemerintah daerah yang sedang berkonflik. Jika, Pemerintah Provinsi Jambi tidak dapat menyelesaikan perkara aset daerah (aset bangunan) tersebut, maka Pemerintah Provinsi Jambi menaikkan surat permohonan bantuan penyelesaian konflik aset daerah (aset bangunan) antara Pemerintah Kabupaten Kerinci dan Pemerintah Kota Sungaipenuh kepada Kementerian Dalam Negeri. c. Penggunaan Tujuan-Tujuan Superordinat yang belum dilaksanakan Pemerintah Provinsi Jambi dalam penyelesaian konflik aset daerah (aset bangunan) antara Pemerintah Kabupaten Kerinci dan Pemerintah Kota Sungaipenuh, rencananya akan di pelajari dan di pertimbangkan terlebih dahulu oleh Pemerintah Provinsi Jambi sebelum didiskusikan kepada Pemerintah Kabupaten Kerinci dan Pemerintah Kota Sungaipenuh.

\section{DAFTAR RUJUKAN}

Antonius dkk. 2002. Empowerment, Stress dan Konflik. Jakarta: Ghalia.

Creswell, John W. 2014. Research Design (Pendekatan Kualitatif, Kuantitatif, dan Mixed). Yogyakarta: Pustaka Belajar.

Hamidi. 2004. Metode Penelitian Kualitatif Pendekatan Praktis Penulisan Proposal dan Laporan Penelitian. Malang: UMM Press.

Irawan, Prasetya. 2007. Penelitian Kualitatif dan Kuantitatif untuk Ilmu-ilmu Sosial. Jakarta: DIA FISIP UI.

Siregar, D. Doli. 2004. Manajemen Aset. Jakarta: Gramedia Pustaka Utama

Wijarjo, Boedi,et.al. 2001. Konflik Bahaya atau Peluang? Panduan latihan Menghadapi dan Menangani Konflik Sumber Daya Alam. Bandung: Pustaka Belajar

Winardi. 2007. Manajemen Konflik. Bandung: Mandar Maju 